\title{
Factors Associated to Cancer Related Fatigue: A Literature Review
}

\author{
Putu Oka Yuli Nurhesti ${ }^{1}$, Made Adi Yudari ${ }^{2}$, Ni Luh Lasiani ${ }^{3}$, Luh Gede Lisnawati ${ }^{4}$, Nyoman Mariani ${ }^{5}$
}

\author{
Bachelor Degree of School of Nursing \\ Faculty of Medicine Udayana University \\ Jimbaran \\ putuokayuli@unud.ac.id \\ Oncology Department Sanglah General Hospital \\ Denpasar \\ Oncology Department Sanglah General Hospital \\ Denpasar \\ Oncology Department Sanglah General Hospital \\ Denpasar \\ Oncology Department Sanglah General Hospital \\ Denpasar
}

\begin{abstract}
Cancer related fatigue is one of the common problems that occur in patients with cancer. This condition is also experienced by cancer patients who receive chemotherapy, radiation therapy, bone marrow transplantation, or other cancer treatments. Continued of cancer related fatigue can disturb the quality of life of patients so that a good assessment and management of this condition is needed. The purpose of this study is for factors related to fatigue in cancer patients. These factors can be new scientific evidence for the treatment of fatigue in cancer patients. This was literature review study. Research data is collected from books, research results, journals, magazines and articles related to the research objectives. The results show that various factors associated to cancer related fatigue discussed in patients are hemoglobin level, type and amount of therapy, sleep quality, nutritional status, level of physical activity, psychological pressure, stress, infection status and comorbidities. Therapy on fatigue patients can be done by overcoming the causal factors.
\end{abstract}

Index Terms - cancer, cancer related fatigue, factors associated

\section{INTRODUCTION}

Cancer related fatigue is one of the common problems that occur in patients with cancer. This condition is also experienced by cancer patients who receive chemotherapy, radiation therapy, bone marrow transplantation, or other cancer treatments. A survey of 1,569 cancer patients was obtained: $80 \%$ of cancer patients who received chemotherapy or radiotherapy said that cancer related fatigue is one of the persistent chief complains. It prevalence would be increased exceeds $75 \%$ in metastasized condition. Patients who experience recovery from cancer reports that cancer related fatigue are taken time months or even spend several years after cancer treatment ends. Continued of cancer related fatigue can disturb the quality of life of patients so that a good assessment and management of this condition is needed [1][2][3][4]. In Indonesia cancer related fatigue is experienced by $67 \%$ of cancer patients both with palliative care and those who have been declared cured [5].

There is considerable variability related to the experience of cancer related fatigue. Individual factors are the main predisposition in the development and persistence of fatigue. Research on genetic, biological, psychosocial, and behavioral risk factors related to cancer related fatigue. 
Taking the multi-factorial nature of this type of fatigue is needed to further explore the various factors that predispose and increase in patients [6].

Quality of life is an important issue in the care of cancer patients. The main goal of treating cancer patients is to promote quality of life. Quality of life is related to cancer management not only to controlling physical symptoms but also in handling psychosocial problems and support for cancer patients. Quality of life is interpreted based on patients' expectations, experiences and trust in health workers, especially nurses [7][8][9]. One of the problems in cancer patients that interfere with quality of life is cancer related fatigue [10].

Cancer related fatigue in Indonesia is often undiagnosed. There are no specific assessment and treatment done by health care providers toward this condition. The purpose of this study is to explore the factors associated to cancer related fatigue. These factors can be new scientific evidence for the treatment of fatigue in cancer patients.

\section{RESEARCH METHODS}

This was literature review study. Research data is collected from books, research results, journals, magazines and articles related to the research objectives.

\section{RESULT AND ANALISYS}

Fatigue is one of the main problems in cancer patients. Various factors associated have been identified through the results of research. Consent and multidisciplinary are the next steps in treatment of cancer related fatigue.

Various obstacles in handling cancer related fatigue are lack of information related to risk factors, mechanisms, signs and symptoms as well as effective treatment of fatigue. Based on studies there are various risk factors for fatigue, such as genetic, psychosocial and biopratic risk factors. Factors related to the inflammatory process, including depression, sleep disorders, physical activity, body mass index, stress, and loneliness [11][12][13]. Accurate analysis of various risk factors for fatigue in cancer patients can be the basis of initial research interventions to overcome cancer related fatigue and improve the quality of life of cancer patients, both patients with palliative care and cancer patients who can recover.

According to Patarca-Montero, [14]; Bray et al [15]; Lamkin, [1]; Kessels, [13] there are several factors associated to cancer related fatigue :

a. Anemia (decrease in red blood cell counts: Anemia causes a decrease in the body's supply of oxygen, nutrients, and energy, causing a person to feel tired.

b. Poor Nutrition: Many cancer patients are at risk of experiencing nutrition-related problems due to loss of appetite or side effects from medications that can cause nausea, vomiting, diarrhea, and reduced absorption of nutrients. Poor nutrition and dehydration can cause a person to feel tired and lethargic. c. Loss of level of physical activity: Someone who is too tired tends not to be able to do physical activity. Reduced physical activity causes loss of muscle mass, and an inability to do daily activities

d. Sleep Disorders: More than half of cancer patients have trouble sleeping, which can cause or worsen fatigue. Patients with cancer report higher levels of insomnia, poor sleep quality, and shorter sleep duration. Fatigue can also cause more sleep during the day, and daytime sleep interferes with sleep patterns at night.

e. Mood Change: Anxiety and depression are the most common psychological causes of fatigue in patients with cancer. Depression affects about 15-25 percent of cancer patients. Symptoms of depression include sadness, loss of interest in previously pleasant activities, difficulty concentrating, fatigue, difficulty sleeping or sleeping too much, and feelings of hopelessness. Overcoming stress from a cancer diagnosis can also cause fatigue by interfering with sleep.

f. Life Stress Due to Cancer: Changes in one's routine and financial pressure due to cancer treatment can also cause fatigue. Money can be a problem if cancer patients need to stop working or reduce working hours. Financial pressures caused by health care costs, lack of health insurance or reduced income can trigger severe stress.

g. Pain: People suffering from blood cancer can experience pain that can interfere with sleep, reduce appetite, limit activity, and cause depression, all of which can increase fatigue. In addition, many opioid analgesics (strong prescription painkillers) have side effects that can cause fatigue.

h. Other Health Problems: Side-by-side comorbidities such as thyroid, infection, sleep apnea, neurological problems, heart, lung, kidney or liver function problems, can also cause or worsen fatigue. Development of hypothyroidism (a condition in which the thyroid gland does not produce enough hormones) can occur after radiation therapy for Hodgkin's lymphoma, non-Hodgkin's lymphoma and after total body radiation in preparation for cell transplantation

\section{CONCLUSION}

Assessment and management of cancer related fatigue is one of the main competencies of health care providers in meeting the basic needs of cancer patients.

\section{ACKNOWLEDGMENT}

The authors thank any parties that support this study, also to Udayana University for financial support.

\section{REFERENCES}

[1] Ackley, B. J., Ladwig, G. B., Swan, B. A., \& Tucker, S. J, "Evidence-based nursing care guidelines: Medical-surgical interventions", St. Louis: Mosby, 2007. 
[2] Neefjes E W., Vandervorst M D L ; Buskermolen A; Verheul H W, "Aiming for a Better Understanding and Management CancerRelated Fatigue", The Oncologist, 2013.

[3] Bower, J., "Cancer-related fatigue: Mechanisms, risk factors, and treatments", Nat Rev Clin Oncol, 2014.

[4] Bourmaud, A. Anota, C. Moncharmont, F. Tinquaut, M. Oriol1, V. Trillet-Lenoir, A. Bajard, S. Parnalland, C. Rotonda, F. Bonnetain, D. Pe' rol and F. Chauvin, "Cancer-Related Fatigue Management: Evaluation of a Patient Education Program With a Large-Scale Randomised Controlled Trial”, The Peps Fatigue Study, 2017.

[5] Effendy, C., "The quality of palliative care for patients with cancer in Indonesia", Radboud Universiteit Nijmegen, 2015.

[6] Seyidova-Khoshknabi D, Davis MP, Walsh D., "Review Article: a Systematic Review of Cancer-Related Fatigue Measurement Questionnaires", Am J Hosp Palliat Care, 2011.

[7] Sudoyo, Aru W, dkk., "Buku Ajar Ilmu penyakit Dalam. Edisi 4, Jilid 1", Jakarta : Departemen Ilmu Penyakit Dalam FKUI, 2007.

[8] A., Geace Pierce, R., Borley Neil, "At a Glance Ilmu Bedah Edisi Ketiga”, Jakarta : Erlangga. 2007.

[9] Chouinard, M.C., Hudon, C., Dubois, M.F., Roberge, P., Loignon, C., Tchouaket, E., Fortin, M., Couture, E.M., and Sasseville, M.. "Case management and self management support for frequent users with chronic disease in primary care: A pragmatic randomized cotrolled trial”, BMC Health Services Research, 2013.

[10] Price, S. A. "Patofisiologi Konsep Klinis Proses Penyakit. Edisi 4", Penerbit Buku Kedokteran EGC, 2010.

[11] Hall A.,E., Boyes A.,W., Bowman J., Walsh R.,A., James E.,L., Girgis A., "Young adult cancer survivors' psychosocial well-being: a cross-sectional study assessing quality of life, unmet needs, and health behaviors", Support Care Cancer, 2012.

[12] Bower, J., "Cancer-related fatigue: Mechanisms, risk factors, and treatments", Nat Rev Clin Oncol, 2014.

[13] Bower, J., "Cancer-related fatigue: Mechanisms, risk factors, and treatments", Nat Rev Clin Oncol, 2014.

[14] Patarca-Montero, " Hand Book of Cancer Related Fatigue”, 2004

[15] Bray F., Jemal A., Grey N., Ferlay J., Forman D., "Global cancer transitions according to the Human Development Index" (20082030): a population-based study", Lancet Oncol, 2012. 